\title{
Evidence for an autumn downstream migration of Atlantic salmon Salmo salar (Linnaeus) and brown trout Salmo trutta (Linnaeus) parr to the Baltic Sea
}

\author{
Imre Taal • Martin Kesler • Lauri Saks • Mehis Rohtla • Aare Verliin • \\ Roland Svirgsden · Kristiina Jürgens $\cdot$ Markus Vetemaa $\cdot$ Toomas Saat
}

Received: 26 February 2014/Revised: 4 April 2014/ Accepted: 7 April 2014/Published online: 20 April 2014

(C) Springer-Verlag Berlin Heidelberg and AWI 2014

\begin{abstract}
In the eastern Baltic rivers, anadromous salmonid parr are known to smoltify and migrate to the sea from March until June, depending on latitude, climate and hydrological conditions. In this study, we present the first records of autumn descent of brown trout Salmo trutta and Atlantic salmon Salmo salar from the Baltic Sea Basin. Otolith microchemistry analyses revealed that these individuals hatched in freshwater and had migrated to the brackish water shortly prior to capture. The fish were collected in 2006, 2008, 2009 and 2013 from Eru Bay (surface salinity 4.5-6.5\%o), Gulf of Finland. This relatively wide temporal range of observations indicates that the autumn descent of anadromous salmonids is not a random event. These results imply that autumn descent needs more consideration in the context of the effective stock management, assessment and restoration of Baltic salmonid populations and their habitats.
\end{abstract}

Keywords Gulf of Finland - Downstream descent . Salmonid parr $\cdot$ Sr:Ca profiles $\cdot$ Otolith microchemistry

Communicated by H.-D. Franke.

I. Taal $(\bowtie) \cdot$ M. Kesler · L. Saks · M. Rohtla · A. Verliin .

R. Svirgsden · K. Jürgens · M. Vetemaa · T. Saat

Estonian Marine Institute, University of Tartu, Vanemuise 46a,

51014 Tartu, Estonia

e-mail: imre.taal@ut.ee

L. Saks

Department of Zoology, Institute of Ecology and Earth Sciences, University of Tartu, Vanemuise 46, 51014 Tartu, Estonia

\section{Introduction}

Juvenile Atlantic salmon, Salmo salar, and anadromous brown trout (sea trout), Salmo trutta, stay in their native river usually for at least one to several years (reviewed in Jonsson and Jonsson 2009a). In the Baltic Sea, anadromous salmonids usually smoltify (an adaptation for coping with transition to saline water) and descend the river to the sea in spring. In the Gulf of Finland, anadromous salmonid parr smoltify and migrate to sea from April to June (Kangur et al. 2003a, b; Kesler et al. 2013). The primary regulating factors of the smolting process are photoperiod and ambient temperature (McCormick et al. 1998), whereas the main factors controlling the timing of the smolt run are water temperature, water flow and changes in these parameters (detailed in Jonsson and Jonsson 2009a).

Besides migration in spring, autumn descent of Atlantic salmon parr has been noted in North American and Great Britain populations (reviewed in Ibbotson et al. 2013), with a significant proportion of the juveniles ( $25 \%$ of the spring smolt run in absolute terms) reported moving to the tidal reaches in at least one study (Pinder et al. 2007). According to Riley et al. (2008), the autumn migrants are not sufficiently physiologically adapted to marine environment. Riley et al. (2009) reported that the adult return rate from autumn-migrating salmon parr appeared to be low. Autumn downstream migration of juvenile anadromous brown trout has been documented in the River Imsa, Norway (Jonsson and Jonsson 2009b). In this case, the survival of autumn descending pre-smolts was very low (Jonsson and Jonsson 2009b). These reports suggest that autumn descending salmonid juveniles may contribute little to the recruitment of the populations. However, it has been suggested (Riley et al. 2009) that the phenomenon of autumn downstream migration still deserves more attention in the context of 
effective management, assessment and restoration of anadromous salmonid populations and their habitats.

To date, there are no scientific evidence of autumn downstream migration of juvenile Atlantic salmon and anadromous brown trout from the Baltic Sea Basin. Therefore, the stock status estimates are based solely on spring smolt abundance, and monitoring programmes do not account the autumn migrations in the Baltic Sea (ICES 2013). This study reports the first observation of an autumn downstream migration of both Atlantic salmon and anadromous brown trout in the Baltic Sea.

\section{Materials and methods}

Juvenile Atlantic salmon and anadromous brown trout were collected from Eru Bay $\left(59^{\circ} 35^{\prime} \mathrm{N} 25^{\circ} 49^{\prime} \mathrm{E}\right)$ located at the southern shore of the Gulf of Finland, Baltic Sea (Fig. 1). Surface water salinity of the bay is 4.5-6.5\%o (Martin et al. 2003) which is typical for the central part of the Gulf of Finland. Although salmonid river Loobu (Kangur et al. 2003a, b) discharges into Eru Bay, the influence of freshwater to the salinity levels in the area is very low (Martin et al. 2003). Sampling was carried out with gillnets and hand (beach) seine (see Taal et al. 2014 for methodological details) in December 2006 and monthly during ice-free season from March to December 2008, April to December 2009, in November and in December 2013. For all caught individuals, total length (TL) and body mass (TW) were recorded and sex determined by visual examination of gonads. Age was determined by counting the translucent zones from unstained otoliths using a stereomicroscope against dark and light background. To infer migration patterns (reviewed by Elsdon et al. 2008), sagittal otoliths were also removed, cleaned and stored in dry microtubes.

Before the chemical analysis, otoliths were ground from the sulcus side until the core area and primordium became visible. Otolith strontium to calcium ratios $(\mathrm{Sr}: \mathrm{Ca})$ were quantified with laser ablation inductively coupled plasma mass spectrometry. The laser was set at $7 \mathrm{~Hz}$ with a $40-\mu \mathrm{m}$ spot size and a scan speed of $5 \mu \mathrm{m} \mathrm{s}^{-1}$. A continuous line scan was traced from the core (excluding the primordium) to dorsal edge of the otolith. Data were handled following the methods of Miller (2007) as described in Rohtla et al. (2014).

\section{Results}

One anadromous brown trout parr was caught on 10 December 2008, by the hand seine haul (no otoliths were collected from that individual). Two additional brown trout were caught with hand seine on 14 November and one in
15 November 2009. All these individuals were females. The first male autumn descending trout parr was collected on 28 December 2013, with hand seine (Table 1). One trout individual was aged as underyearling and all the others as yearlings (Table 1).

One female autumn descending Atlantic salmon parr was caught on 7 December 2006, with hand seine. A second female salmon was collected on 15 November 2009, with gillnet, with a third female salmon collected on 27 December 2013, using a hand seine. The first descending spent male salmon parr was collected on 28 December 2013, with gillnet (Table 1). Parr status of both salmon and trout was confirmed by visual observation of strong markings accompanied with no signs of smoltification.

Otolith Sr:Ca profiles confirmed that all sampled individuals hatched in freshwater (Fig. 2). Still, the peaks in the beginning of the $\mathrm{Sr}$ :Ca profiles represented maternally derived seawater signal (Kalish 1990). According to Miller (2011), the change in otolith Sr:Ca profile becomes evident during 2-3 days and reaches a plateau latest 2 weeks after the smolt has migrated to the sea. Two trout individuals in

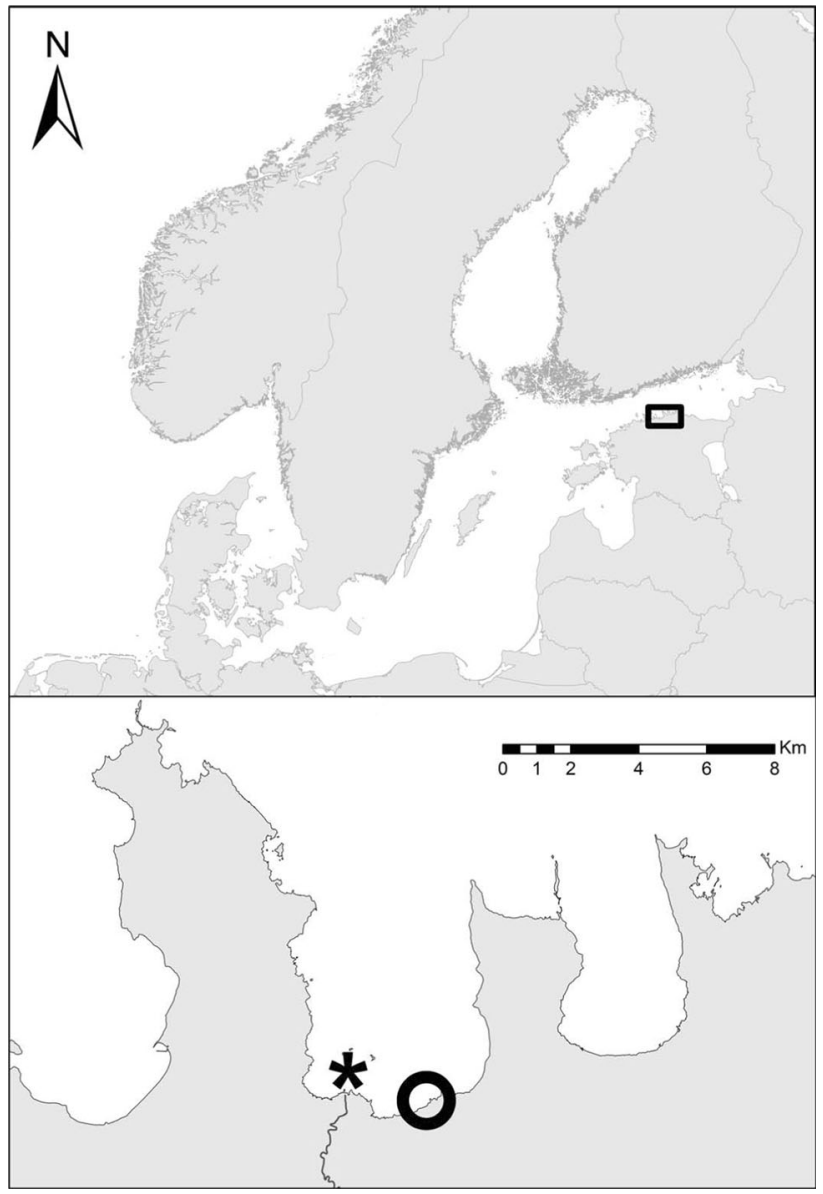

Fig. 1 Map of the study area (circle location of the sampling site, asterisk river mouth of the Loobu River) 
Table 1 Individual parameters of autumn descending Atlantic salmon and anadromous brown trout parr
TL is presented in millimetres and TW in grams

\begin{tabular}{|c|c|c|c|c|c|c|c|}
\hline Species & Age & Sex & Maturity & $\mathrm{TL}$ & $\mathrm{TW}$ & Sea days & Date \\
\hline S. salar & Underyearling & Female & Juvenile & 130 & 17.7 & $14-28$ & 7 December 2006 \\
\hline S. salar & Yearling & Female & Juvenile & 148 & 26.9 & $2-7$ & 15 November 2009 \\
\hline S. salar & Yearling & Female & Juvenile & 140 & 21.4 & $2-7$ & 27 December 2013 \\
\hline S. salar & Yearling & Male & Spent & 155 & 29.6 & $2-7$ & 28 December 2013 \\
\hline S. trutta & & Female & Juvenile & 101 & 7.9 & & 10 December 2008 \\
\hline S. trutta & Underyearling & Female & Juvenile & 98 & 8.9 & $<2-3$ & 14 November 2009 \\
\hline S. trutta & Yearling & Female & Juvenile & 121 & 17.8 & $2-7$ & 14 November 2009 \\
\hline S. trutta & Yearling & Female & Juvenile & 146 & 26.9 & $<2-3$ & 15 November 2009 \\
\hline S. trutta & Yearling & Male & Juvenile & 155 & 27.1 & $2-7$ & 28 December 2013 \\
\hline
\end{tabular}

our data set had descended to the sea less than 2-3 days (Table 1) before capture (i.e. no sea water signal in the profile; Fig. 2a). Most individuals had descended to the sea within 2-7 days (Table 1) prior to capture (i.e. minimal to moderate sea water signal; Fig. 2b). Only one salmon (Table 1) had descended to the sea more than 2 weeks (but no more than 4 weeks) before the capture (i.e. plateau in the profile; Fig. 2c).

\section{Discussion}

Results from the present study show that the autumn descent of anadromous salmonids occurs in the Baltic Sea. The parr phenotype of autumn descending anadromous brown trout and Atlantic salmon in this study is in accordance with previous results reviewed, e.g. by Youngson et al. (1983), Riley et al. (2008) and Jonsson and Jonsson (2009b). The autumn migration of Atlantic salmon parr has been associated with high flows (Youngson et al. 1983), but it is not clear why only a proportion of the population follows the autumn migration strategy. It is also unclear whether these two groups of fish differ in their genetic origin (Ibbotson et al. 2013). Ibbotson et al. (2013) reviewed a number of potential mechanisms that trigger autumn migration of Atlantic salmon, including intrinsic factors such as size and position in the dominance hierarchy and extrinsic factors associated with density and habitat, related to the supply of food, cover (shelter availability) and the presence of predators. These hypotheses may also be relevant for brown trout as the phylogeny and life history of this species are similar to Atlantic salmon (reviewed by Jonsson and Jonsson 2009b, but see also Limburg et al. 2001).

To our knowledge, our results are the first documentation of autumn downstream migration of juvenile Atlantic salmon and anadromous brown trout from the Baltic Sea Basin. However, it has been reported that fry and parr of anadromous brown trout from small Gotland streams (with high number of spawners and decreasing water levels
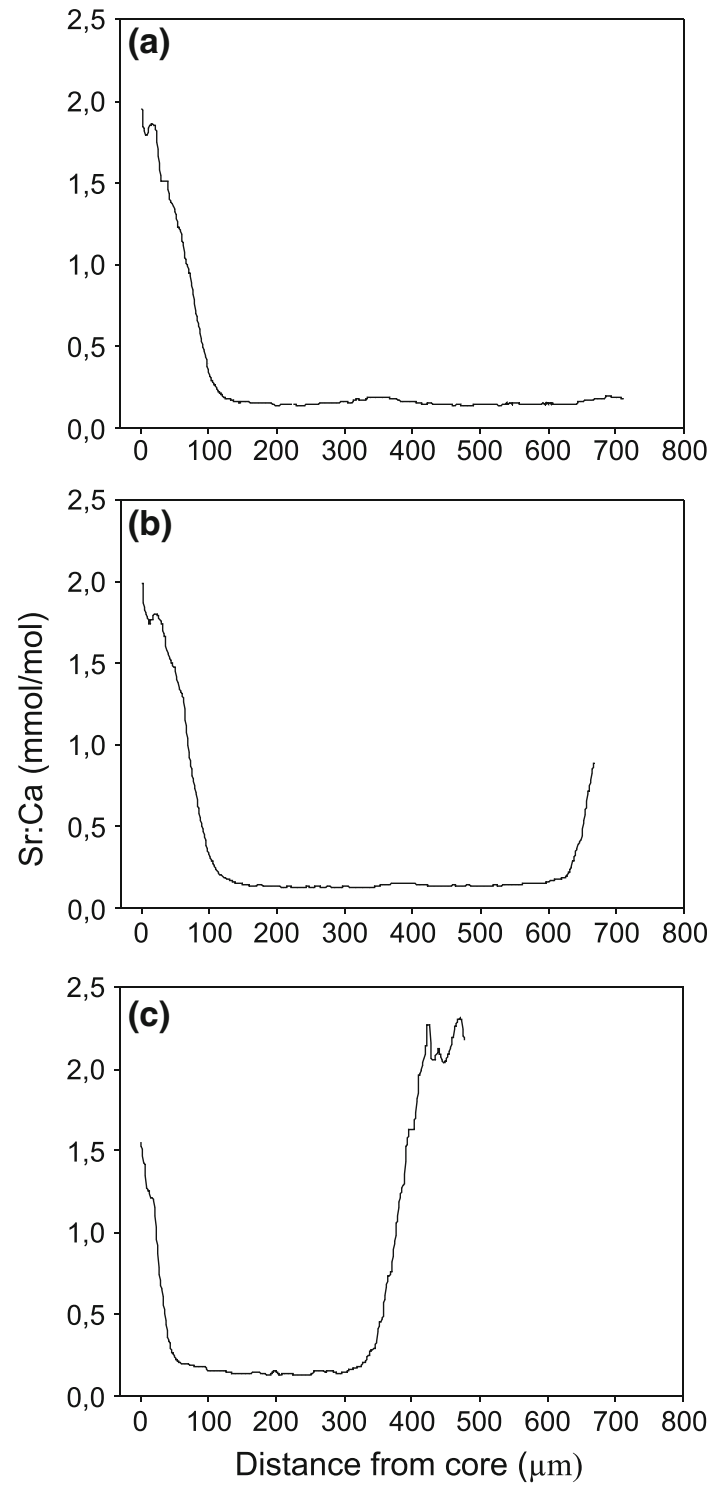

Fig. 2 Examples of $\mathrm{Sr}: \mathrm{Ca}$ profiles. a Anadromous brown trout collected from the sea on 14 November 2009, with no seawater signal; b salmon collected from the sea on 28 December 2013, with moderate seawater signal; $\mathbf{c}$ salmon collected from the sea on 07 December 2006, with stabilized seawater signal. The peaks in the beginning of the $\mathrm{Sr}: \mathrm{Ca}$ profiles represent maternally derived seawater signal (Kalish 1990) 
during spring and summer) move to sea soon after hatching in spring and early summer (Landegren and Vallin 1998; Landegren 2001; Landergren 2004). Still, these observations from Gotland do not contradict the conclusions of the present study, as we report data on autumn migration of juvenile anadromous brown trout, not on spring-summer descent of parr immediately after hatching.

Riley et al. (2008) reported that autumn-migrating Atlantic salmon parr are not yet physiologically adapted to saline water (i.e. expected survivability in the ocean is very poor) and therefore overwinter in estuaries. Still, autumn migrants have been detected returning as sea run adults (Riley et al. 2009). In the River Imsa, few of the juvenile anadromous brown trout descending to the estuary in autumn and winter survived until adulthood and returned to the river (Jonsson and Jonsson 2009b). However, it has been experimentally demonstrated (Landegren 2001) that the brackish Baltic Sea water (6-7 \%o, e.g. around Gotland island) is not a physiological obstacle for the survival of early out-migrating anadromous brown trout parr. Moreover, these results (Landegren 2001) suggested that anadromous brown trout parr descending from freshwater to the brackish Baltic coastal zone, without smolting, may experience little or no physiological cost in survival and growth. The Gulf of Finland in the Baltic Sea is a brackish ecosystem with very low surface water salinity, increasing from $<1.0 \%$ in the East to $6.0 \%$ in the West (Lappalainen et al. 2000). Thus, it may be possible for autumn descending Atlantic salmon parr to survive and thrive in this expansive brackish marine environment, while the sea survival of brown trout parr may be higher than previously reported from more saline regions (Jonsson and Jonsson 2009b).

In conclusion, our results suggest that autumn descent of salmonid parr in less-saline parts of the Baltic Sea need more consideration at least in the context of life history individual recruitment strategy and the management and restoration of salmonid populations and their habitats.

Acknowledgments We thank Anu Albert, Kalvi Hubel, Katri Kalda, Risto Kalda, Kairi Kullasepp, Snežana Nedolgova, Ulvi Päädam, Mari-Liis Põlme, Kateriina Rumvolt, Silver Sirp, Andro Mesi Truuverk, Tiiu Tõrra and Erki Õunap for help during fieldworks and anonymous referees for their constructive criticism of the manuscript. Funding for this research was provided by Estonian Science Foundation grant 8281 and target financed project SF0180005s10.

\section{References}

Elsdon TS, Wells BK, Campana SE, Gillanders BM, Jones CM, Limburg KE, Secor DH, Thorrold SR, Walther BD (2008) Otolith chemistry to describe movements and life-history measurements of fishes: hypotheses, assumptions, limitations, and inferences using five methods. In: Gibson RN, Atkinson
RJA, Gordon JDM (eds) Oceanography and marine biology: an annual review, vol 46. Taylor \& Francis, London, pp 297-330

Ibbotson AT, Riley WD, Beaumont WRC, Cook AC, Ives MJ, Pinder AC, Scott LJ (2013) The source of autumn and spring downstream migrating juvenile Atlantic salmon in a small lowland river. Ecol Freshw Fish 22:73-81. doi:10.1111/eff. 12003

ICES (2013) Report of the Baltic Salmon and Trout Assessment Working Group (WGBAST), 3-12 Apr 2013, Tallinn, Estonia. ICES CM 2013/ACOM:08

Jonsson B, Jonsson N (2009a) A review of the likely effects of climate change on anadromous Atlantic salmon Salmo salar and brown trout Salmo trutta, with particular reference to water temperature and flow. J Fish Biol 75:2381-2447. doi:10.1111/j. 1095-8649.2009.02380.x

Jonsson B, Jonsson N (2009b) Migratory timing, marine survival and growth of anadromous brown trout Salmo trutta in the River Imsa, Norway. J Fish Biol 74:621-638. doi:10.1111/j.10958649.2008.02152.x

Kalish JM (1990) Use of otolith microchemistry to distinguish the progeny of sympatric anadromous and non-anadromous salmonids. Fish Bull NOAA 88:657-666

Kangur M, Paaver T, Drevs T (2003a) Salmon, Salmo salar L. In: Ojaveer E, Saat T, Pihu E (eds) Fishes of Estonia. Estonian Academy, Tallinn, pp 91-97

Kangur M, Paaver T, Drevs T, Turovski A (2003b) Sea trout, Salmo trutta L. In: Ojaveer E, Saat T, Pihu E (eds) Fishes of Estonia. Estonian Academy, Tallinn, pp 97-104

Kesler M, Vetemaa S, Saks L, Saat T (2013) Survival of reared Atlantic salmon (Salmo salar) smolts during downstream migration and its timing: a case study in the Pirita River. Boreal Env Res 18:53-60

Landegren P (2001) Survival and growth of sea trout parr in fresh and brackish water. J Fish Biol 58:591-593. doi:10.1111/j.10958649.2001.tb02275.x

Landegren P, Vallin L (1998) Spawning of sea trout, Salmo trutta L., in brackish waters-lost effort or successful strategy? Fish Res 35:229-236. doi:10.1016/S0165-7836(98)00073-3

Landergren P (2004) Factors affecting early migration of sea trout Salmo trutta parr to brackish water. Fish Res 67:283-294. doi:10.1016/j.fishres.2003.10.005

Lappalainen A, Shurukhin A, Alekseev G, Rinne J (2000) Coastal-fish communities along the northern coast of the Gulf of Finland, Baltic Sea: responses to salinity and eutrophication. Int Rev Hydrobiol 85:687-696. doi:10.1002/1522-2632(200011)85:5/ 6<687:AID-IROH687>3.0.CO;2-4

Limburg KE, Landergren P, Westin L, Elfman M, Kristiansson P (2001) Flexible modes of anadromy in Baltic Sea trout: making the most of marginal spawning streams. J Fish Biol 59:682-695. doi:10.1111/j.1095-8649.2001.tb02372.x

Martin G, Torn K, Kotta J, Orav-Kotta H (2003) Estonian marine phytobenthos monitoring programme: preliminary results and future perspectives. Proc Est Acad Sci Biol Ecol 52:112-124

McCormick SD, Hansen LP, Quinn TP, Saunders RL (1998) Movement, migration, and smolting of Atlantic salmon (Salmo salar). Can J Fish Aquat Sci 55:77-92. doi:10.1139/d98-011

Miller JA (2007) Scales of variation in otolith elemental chemistry of juvenile staghorn sculpin (Leptocottus armatus) in three Pacific Northwest estuaries. Mar Biol 151:483-494. doi:10.1007/ s00227-006-0477-z

Miller JA (2011) Effects of water temperature and barium concentration on otolith composition along a salinity gradient: implications for migratory reconstructions. J Exp Mar Biol Ecol 405:42-52. doi:10.1016/j.jembe.2011.05.017

Pinder AC, Riley WD, Ibbotson AT, Beaumont WRC (2007) Evidence for an autumn downstream migration and the 
subsequent estuarine residence of $0+$ juvenile Atlantic salmon, Salmo salar L., in England. J Fish Biol 71:260-264. doi:10.1111/ j.1095-8649.2007.01470.x

Riley WD, Ibbotson AT, Lower N, Cook AC, Moore A, Mizuno S, Pinder AC, Beaumont WRC, Privitera L (2008) Physiological seawater adaptation in juvenile Atlantic salmon (Salmo salar) autumn migrants. Freshw Biol 53:745-755. doi:10.1111/j.13652427.2007.01933.x

Riley WD, Ibbotson AT, Beaumont WRC (2009) Adult returns from Atlantic salmon, Salmo salar, parr autumn migrants. Fish Manag Ecol 16:75-76. doi:10.1111/j.1365-2400.2008.00643.x

Rohtla M, Vetemaa M, Taal I, Svirgsden R, Urtson K, Saks L, Verliin A, Kesler M, Saat T (2014) Life history of anadromous burbot
(Lota lota, Linneaus) in the brackish Baltic Sea inferred from otolith microchemistry. Ecol Freshw Fish 23:141-148. doi:10. 1111/eff.12057

Taal I, Saks L, Nedolgova S, Verliin A, Kesler M, Jürgens K, Svirgsden R, Vetemaa M, Saat T (2014) Diet composition of smelt Osmerus eperlanus (Linnaeus) in brackish near-shore ecosystem (Eru Bay, Baltic Sea). Ecol Freshw Fish 23:121-128. doi:10.1111/eff.12044

Youngson AF, Buck RJG, Simpson TH, Hay DW (1983) The autumn and spring emigrations of juvenile Atlantic salmon, Salmo salar L., from the Girnock Burn, Aberdeenshire, Scotland: environmental release of migration. J Fish Biol 23:625-639. doi:10.111/ j.1095-8649.1983.tb02942.x 